\title{
PF1018, A NOVEL INSECTICIDAL COMPOUND PRODUCED BY Humicola sp. ${ }^{\dagger}$
}

\author{
Shuichi Gomi, Kei-ichi Imamura, Takashi Yaguchi, Yoshio Kodama, \\ Nobuto Minowa and Masao Koyama. \\ Pharmaceutical Research Center, Meiji Seika Kaisha, Ltd., \\ Morooka-cho, Kohoku-ku, Yokohama 222, Japan
}

(Received for publication November 15, 1993)

\begin{abstract}
A new insecticidal compound PF1018 was isolated from the culture broth of Humicola sp. It exhibited insecticidal activity against a wide range of critical pest species. The structure of PF 1018 was determined to be $(7 \mathrm{a} S)-2-((2 E)-1$-hydroxy-3- $((1 S, 3 \mathrm{a} R, 4 R, 5 R, 7 \mathrm{a} R)-3 \mathrm{a}, 4,5,7 \mathrm{a}-$ tetrahydro-1,3,5,7tetramethyl-5,1-((3S)-(Z)-2,3-dimethylpropeno)-1 $H$-inden-4-yl)-2-propenylidene)pyrrolizidine1,3-dione, by NMR spectral analyses coupled with X-ray crystallographic analysis and chemical degradation study.
\end{abstract}

In the course of our screening program for new insecticidal compounds from microbial origin, a fungal strain identified as Humicola sp. PF1018 was found to produce a new insecticidal compound designated PF1018. The compound showed significant insecticidal activity against a variety of pest species, especially, a wild type strain of Plutella xylostella. The structure of PF1018 was established by means of spectral analyses, X-ray diffraction analysis and by chemical studies. PF1018 possesses a unique tricyclo-aliphatic side chain coupled with a conjugated triketone system as in tenuazonic acid. In this paper, the taxonomy and fermentation of the producing strain, isolation, physico-chemical properties, structural elucidation and biological activities of PF1018 are reported.

Taxonomy of the Producing Strain

The producing microorganism, strain PF1018, was isolated from a soil sample collected at Ohmachi City, Nagano Prefecture, Japan. Mycological characteristics of strain PF1018 were as follows. On potato-dextrose agar (PDA) at $25^{\circ} \mathrm{C}$, colonies reached a diameter of 8 to $10 \mathrm{~mm}$ after 7 days and 20 to $22 \mathrm{~mm}$ after 14 days incubation. Colonies were plane, velvety, white to pale yellow at first, turning pale grey to dark grey with the production of conidia, and showed no growth at $37^{\circ} \mathrm{C}$. The reverse side of the colonies was pale orange, turning dark grey. No soluble pigment was formed. On potato - carrot agar, malt extract agar and oatmeal agar, the colonies showed similar characteristics described on PDA. Mycelia were superficial to somewhat immersed, composed of smooth-walled, branched, septate, hyline, $1.5 \sim 3.0 \mu \mathrm{m}$ in diameter. Conidia were aleurioconidia, brown to dark grey, obovoid or pyriform, smooth, unicellular, $6.0 \sim 8.0 \times 4.5 \sim 5.5 \mu \mathrm{m}$ in dia-

Fig. 1. Scanning electron micrograph of strain PF1018 grown on oatmeal agar medium.

Bar represents $5 \mu \mathrm{m}$.

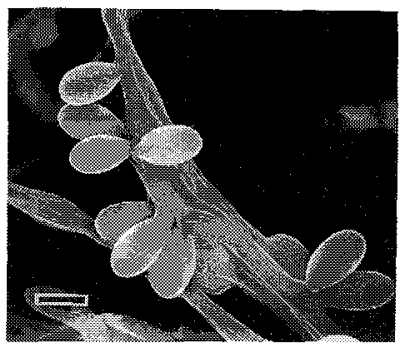

$\uparrow$ Most of this work was reported at the annual meeting of the Japan Society for Bioscience, Biotechnology, and Agrochemistry held in Kyoto on April 1, 1991. 
meter, produced singly either directly on the sides of vegetative hyphae or on short lateral conidiophores. No phialidic conidia were found. Scanning electron micrograph of this strain was shown in Fig. 1.

The above characteristics of strain PF1018 indicate that this fungus belongs to the genus Humicola. Among the species of Humicola, it is considered to be similar to Humicola piriformis ${ }^{1)}$, however, we did not attempt the determination of the species.

\section{Fermentation}

Humicola sp. PF1018 was precultured in a 100-ml Erlenmeyer flask containing $20 \mathrm{ml}$ of a seed medium composed of starch $2.0 \%$, glucose $1.0 \%$, wheat germ $0.6 \%$, peptone $0.5 \%$, yeast extract $0.3 \%$, soybean meal $0.2 \%$ and $\mathrm{CaCO}_{3} 0.1 \%$ (pH 7 before sterilization) at $26^{\circ} \mathrm{C}$ for 5 days on a rotary shaker at $210 \mathrm{rpm}$. Four $\mathrm{ml}$ of the first seed culture was inoculated into $500-\mathrm{ml}$ Erlenmeyer flasks each containing $80 \mathrm{ml}$ of the same seed medium. The culture was grown on a rotary shaker $(210 \mathrm{rpm})$ at $26^{\circ} \mathrm{C}$ for 3 days to give a second seed culture.

Four hundred $\mathrm{ml}$ of the second seed culture was transferred into two 50 -liter jar fermentors each containing 35 liters of a medium consisting starch $2.0 \%$, glucose $2.0 \%$, soybean powder $1.0 \%$, wheat germ $1.0 \%$, meat extract $0.5 \%, \mathrm{NaCl} 0.2 \%, \mathrm{CaCO}_{3} 0.3 \%, \mathrm{MgSO}_{4} \cdot 7 \mathrm{H}_{2} \mathrm{O} 0.1 \%$ and $\mathrm{ZnSO}_{4} \cdot 7 \mathrm{H}_{2} \mathrm{O} 0.001 \%$ (pH 7 before sterilization). Fermentation was carried out under aeration at 20 liters per minute and agitation at $250 \mathrm{rpm}$ in the early stage and at $400 \mathrm{rpm}$ after 41 hours. Production of PF1018 was monitored by high performance liquid chromatography (HPLC) described in the experimental section.

\section{Isolation}

The fermentation broth ( $c a .60$ liters) was filtered and the mycelial cake was extracted with $60 \%$ aqueous acetone (50 liters). After removal of acetone, the concentrate was extracted twice with ethyl acetate (20 liters). The extracts were concentrated to give a yellow oil $(16 \mathrm{~g})$. The oily substance was applied to a silica gel column $(700 \mathrm{~g})$ and chromatographed using a mixture of hexane and acetone $(4: 1)$. The fractions containing PF1018 were concentrated to dryness. The resultant oil was chromatographed on a silica gel column $(20 \mathrm{~g})$ developed with a mixture of chloroform and methanol (100:1) to yield a crude PF1018 $(232 \mathrm{mg})$. The crude substance was dissolved in chloroform $(120 \mathrm{ml})$, washed with $0.01 \mathrm{~N} \mathrm{HCl}(120 \mathrm{ml})$ and concentrated to dryness to afford a yellow powder. Further purification of the powder was achieved by Sephadex LH-20 (600 ml) column chromatography developed with methanol followed by crystallization from methanol to give pure PF1018 (123 mg) as pale yellow crystals.

\section{Physico-chemical Properties}

PF1018 (1) was soluble in chloroform, ethyl acetate, acetone and methanol but insoluble in water. 1 showed an Rf value of 0.64 (chloroform methanol, 20:1) on TLC and gave positive color reactions with $\mathrm{FeCl}_{3}, \mathrm{H}_{2} \mathrm{SO}_{4}$ and $\mathrm{Na}_{2} \mathrm{MoO}_{4}$ $\mathrm{H}_{2} \mathrm{SO}_{4}$ reagents and negative with Ninhydrin reagent. It has weak acidic nature and was stable in neutral or alkaline solution $(0.1 \mathrm{~N} \mathrm{NaOH}-\mathrm{MeOH}$,

Table 1. Physico-chemical properties of PF1018.

\begin{tabular}{|c|c|}
\hline Appearance & Pale yellow crystals \\
\hline $\mathrm{MP}\left({ }^{\circ} \mathrm{C}\right.$, dec $)$ & $182 \sim 184$ \\
\hline$[\alpha]_{\mathrm{D}}^{24}$ & $-185^{\circ}\left(c 1.0, \mathrm{CHCl}_{3}\right)$ \\
\hline Molecular formula & $\mathrm{C}_{28} \mathrm{H}_{35} \mathrm{NO}_{3}$ \\
\hline HREI-MS Caicd: & $433.2615\left(\mathrm{M}^{+}\right)$ \\
\hline Found: & $433.2677\left(\mathrm{M}^{+}\right)$ \\
\hline Elemental analysis & (Calcd for $\mathrm{C}_{28} \mathrm{H}_{35} \mathrm{NO}_{3} \cdot \mathrm{H}_{2} \mathrm{O}$ ) \\
\hline Calcd: & C $74.47, \mathrm{H} 8.26, \mathrm{~N} 3.10$ \\
\hline Found: & C 75.08, H 8.06, N 3.38 \\
\hline $\mathrm{UV} \lambda_{\max }^{\mathrm{MeOH}} \mathrm{nm}\left(\mathrm{E}_{1 \mathrm{~cm}}^{1 \%}\right)$ & $251(294), 320(355)$ \\
\hline $\begin{array}{l}\lambda_{\max }^{\mathrm{MeOH}-\mathrm{HCl}} \mathrm{nm} \\
\left(\mathrm{E}_{1 \mathrm{~cm}}^{1 \%}\right)\end{array}$ & $235(229), 332(471)$ \\
\hline $\begin{array}{l}\lambda_{\max }^{\mathrm{MeOH}-\mathrm{NaOH}} \mathrm{nm} \\
\left(\mathrm{E}_{1 \mathrm{~cm}}^{1 \%}\right)\end{array}$ & $254(326), 316(340)$ \\
\hline IR $v_{\max }(\mathrm{KBr}) \mathrm{cm}^{-1}$ & $\begin{array}{l}3410,2960,2925,2870,1710 \\
\quad 1640,1580,1430\end{array}$ \\
\hline
\end{tabular}


$1: 9)$. But it gradually decomposed in acidic solution $(0.1 \mathrm{~N} \mathrm{HCl}-\mathrm{MeOH}, 1: 9)$ and its remaining ratio was less than $10 \%$ at room temperature after 2 days on the basis of HPLC analysis. The other physico-chemical properties of 1 are summarized in Table 1 , and ${ }^{1} \mathrm{H}$ and ${ }^{13} \mathrm{C}$ NMR data are listed in Tables 2 and 3 , respectively.

Table 2. ${ }^{1} \mathrm{H}$ NMR data of PF 1018.

\begin{tabular}{|c|c|c|}
\hline \multirow{2}{*}{ Proton } & Major form & Minor form \\
\hline & $\delta \mathbf{M}(J, \mathbf{H z})$ & $\delta \mathrm{M}(J, \mathrm{~Hz})$ \\
\hline $2-\mathrm{H}$ & 5.03 brs & $5.03 \mathrm{br} \mathrm{s}$ \\
\hline $3 a-H$ & 2.50 brd $(9.7)$ & 2.50 brd $(9.7)$ \\
\hline $4-\mathrm{H}$ & $2.41 \mathrm{~m}$ & 2.43 brd $(10.1)$ \\
\hline $6-\mathrm{H}$ & 5.37 brs & $5.37 \mathrm{brs}$ \\
\hline $7 a-H$ & $2.62 d(9.7)$ & $2.62 \mathrm{~d}(9.7)$ \\
\hline $8-\mathrm{H}$ & $4.91 \mathrm{brs}$ & 4.91 brs \\
\hline $10-\mathrm{H}$ & 2.83 brq (7.5) & 2.83 br q $(7.5)$ \\
\hline $11-\mathrm{H}_{3}$ & $1.22 \mathrm{brs}$ & $1.22 \mathrm{brs}$ \\
\hline $12-\mathrm{H}_{3}$ & $1.73 \mathrm{brs}$ & $1.72 \mathrm{brs}$ \\
\hline $13-\mathrm{H}_{3}$ & 0.95 brs & 0.95 brs \\
\hline $14-\mathrm{H}_{3}$ & 1.82 brd $(1.5)$ & 1.83 brd (1.5) \\
\hline $15-\mathrm{H}_{3}$ & 1.43 br d $(0.8)$ & 1.43 brd $(0.8)$ \\
\hline $16-\mathrm{H}_{3}$ & $0.92 \mathrm{~d}(7.5)$ & $0.92 \mathrm{~d}(7.4)$ \\
\hline $17-\mathrm{H}$ & $7.01 \mathrm{~m}$ & $7.04 \mathrm{dd}(15.6,10.1)$ \\
\hline $18-\mathrm{H}$ & $7.00 \mathrm{~m}$ & $7.12 \mathrm{~d}(15.6)$ \\
\hline $19-\mathrm{OH}$ & $12.35 \mathrm{br}$ & $12.35 \mathrm{br}$ \\
\hline $5^{\prime}-\mathrm{H}_{2}$ & $\begin{array}{l}3.27 \text { ddd }(11.5,8.7,3.8) \\
3.75 \text { ddd }(11.5,7.8,7.8)\end{array}$ & $\begin{array}{l}3.22 \text { ddd }(11.5,8.5,4.1) \\
3.79 \text { ddd }(11.5,8.0,8.0)\end{array}$ \\
\hline $6^{\prime}-\mathrm{H}_{2}$ & $2.04 \sim 2.22 \mathrm{~m}$ & $2.04 \sim 2.22 \mathrm{~m}$ \\
\hline $7^{\prime}-\mathrm{H}_{2}$ & $\begin{array}{l}1.55 \text { dddd }(12.1,10.3,10.3,8.2) \\
2.17 \mathrm{~m}\end{array}$ & $\begin{array}{l}1.55 \text { dddd }(12.1,10.3,10.0,8.2) \text {, } \\
2.17 \mathrm{~m}\end{array}$ \\
\hline $7 \mathrm{a}-\mathrm{H}$ & $3.96 \mathrm{dd}(10.3,6.9)$ & $4.06 \mathrm{dd}(10.0,6.9)$ \\
\hline
\end{tabular}

$\delta:$ ppm from TMS in $\mathrm{CDCl}_{3}$.

M: Multiplicity.

Table 3. ${ }^{13} \mathrm{C}$ NMR data of PF1018.

\begin{tabular}{|c|c|c|c|c|c|}
\hline \multirow{2}{*}{ Carbon } & \multirow{2}{*}{$\frac{\text { Major form }}{\delta \mathrm{M}}$} & \multirow{2}{*}{ Minor form } & \multirow{2}{*}{ Carbon } & Major form & \multirow{2}{*}{ Minor form } \\
\hline & & & & $\delta \quad \mathbf{M}$ & \\
\hline C-1 & $60.78 \mathrm{~s}$ & 60.78 & C-13 & $29.75 q$ & 29.71 \\
\hline $\mathrm{C}-2$ & $128.60 \mathrm{~d}$ & 128.60 & C-14 & $24.14 \mathrm{q}$ & 24.14 \\
\hline $\mathrm{C}-3$ & $140.67 \mathrm{~s}$ & 140.64 & C-15 & $24.76 \mathrm{q}$ & 24.76 \\
\hline C-3a & $54.36 \mathrm{~d}$ & 54.28 & C-16 & $15.30 \mathrm{q}$ & 15.30 \\
\hline C-4 & $53.31 \mathrm{~d}$ & 53.46 & C-17 & $154.69 \mathrm{~d}$ & 155.63 \\
\hline $\mathrm{C}-5$ & $41.06 \mathrm{~s}$ & 41.06 & C-18 & $120.08 \mathrm{~d}$ & 119.62 \\
\hline$C-6$ & $126.45 \mathrm{~d}$ & 126.45 & C-19 & $174.34 \mathrm{~s}$ & 175.71 \\
\hline $\mathrm{C}-7$ & $138.94 \mathrm{~s}$ & 138.94 & $C-1^{\prime}$ & $194.98 \mathrm{~s}$ & 203.72 \\
\hline C-7a & $55.33 \mathrm{~d}$ & 55.33 & $\mathrm{C}-2^{\prime}$ & $101.27 \mathrm{~s}$ & 103.70 \\
\hline C-8 & $132.10 \mathrm{~d}$ & 132.05 & $C-3^{\prime}$ & $177.57 \mathrm{~s}$ & 170.76 \\
\hline C-9 & $139.38 \mathrm{~s}$ & 139.43 & $C-5^{\prime}$ & $43.12 \mathrm{t}$ & 43.32 \\
\hline C- 10 & $37.37 \mathrm{~d}$ & 37.37 & C- $6^{\prime}$ & $26.85 \mathfrak{t}^{\mathrm{a}}$ & $27.12^{\mathrm{a}}$ \\
\hline$C-11$ & $27.63 \mathrm{q}$ & 27.63 & $\mathrm{C}-7^{\prime}$ & $26.82 \mathfrak{t}^{\mathfrak{a}}$ & $27.01^{\mathrm{a}}$ \\
\hline C-12 & $14.60 \mathrm{q}$ & 14.60 & C- $7^{\prime} \mathrm{a}$ & $68.73 \mathrm{~d}$ & 66.37 \\
\hline
\end{tabular}

$\delta:$ ppm from TMS in $\mathrm{CDCl}_{3}$.

M: Multiplicity.

a Interchangeable. 
Structural Elucidation

The molecular formula of 1 was established to be $\mathrm{C}_{28} \mathrm{H}_{35} \mathrm{NO}_{3}$ by high resolution EI-MS, ${ }^{1} \mathrm{H}$ and ${ }^{13} \mathrm{C}$ NMR spectra and elemental analysis. It showed strong absorption bands at 1710,1640 and $1580 \mathrm{~cm}^{-1}$, and very weak absorption around $1100 \mathrm{~cm}^{-1}$ in the IR spectrum, suggesting the presence of ketone, amide and olefin, and no ether bond, respectively. Its strong UV absorption at $320 \mathrm{~nm}$ revealed that 1 possessed a chromophore consisting of three or more conjugated double bonds $(C=C, C=O)$. In the ${ }^{1} H$ and ${ }^{13} \mathrm{C}$ NMR spectra of 1 in $\mathrm{CDCl}_{3}$ shown in Figs. 2 and 3, several signals accompanied by corresponding minor peaks were observed. In the case where $\mathrm{H}_{2} \mathrm{O}$ or $\mathrm{D}_{2} \mathrm{O}$ was added into $\mathrm{CDCl}_{3}$ solution of 1 , the two separated proton signals at $\delta 3.27 / 3.22, \delta 3.75 / 3.79, \delta 3.96 / 4.06$ and about $\delta 7.0$ for the same nucleus in $\mathrm{CDCl}_{3}$ were observed as some broadening averaged signals. Furthermore, in $\mathrm{CD}_{3} \mathrm{OD}$ solution, the two sets of carbon signals having large chemical shift difference observed at about $\delta 68, \delta 102$ and at lower field than $\delta 170$ in $\mathrm{CDCl}_{3}$ coslesced each other to disappear in a noise level. Therefore, it was deduced that PF1018 exists as a mixture of two tautomers in these solutions and that a rate of isomerization between two tautomers in protic solvent is much faster than that in aprotic solvent. In order to clarify a partial structure causing the tautomerism, ${ }^{1} \mathrm{H}-{ }^{1} \mathrm{H}$ COSY,${ }^{1} \mathrm{H}-{ }^{13} \mathrm{C}$ COSY, heteronuclear multiple band correlation

Fig. 2. ${ }^{1} \mathrm{H}$ NMR spectrum of PF1018.

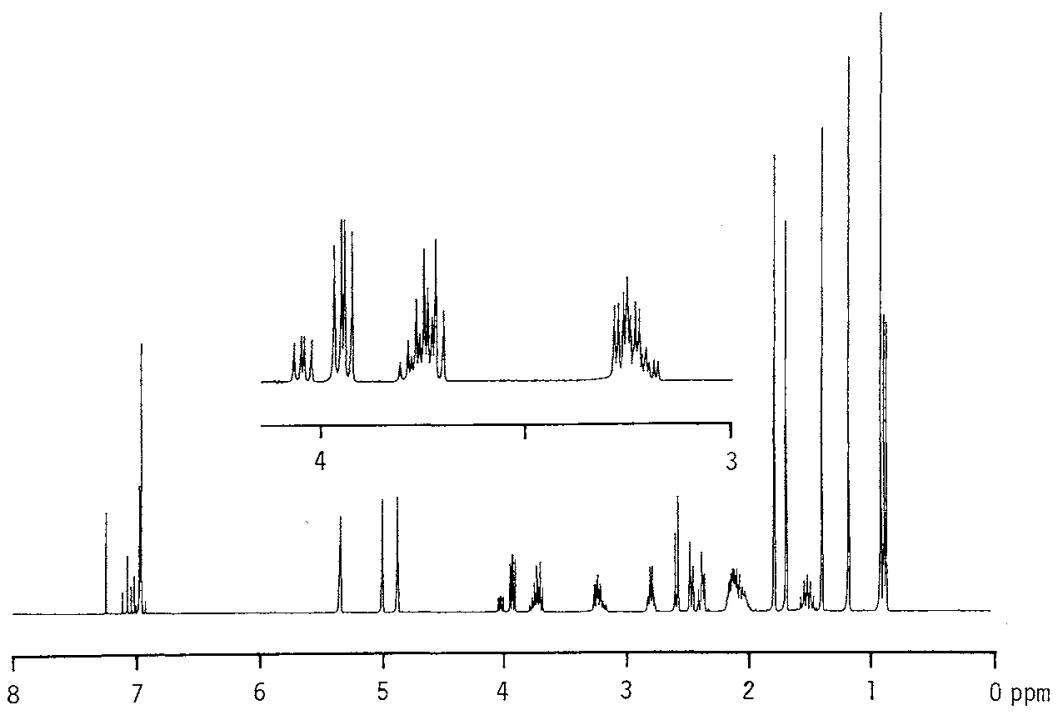

Fig. 3. ${ }^{13} \mathrm{C}$ NMR spectrum of PF1018.

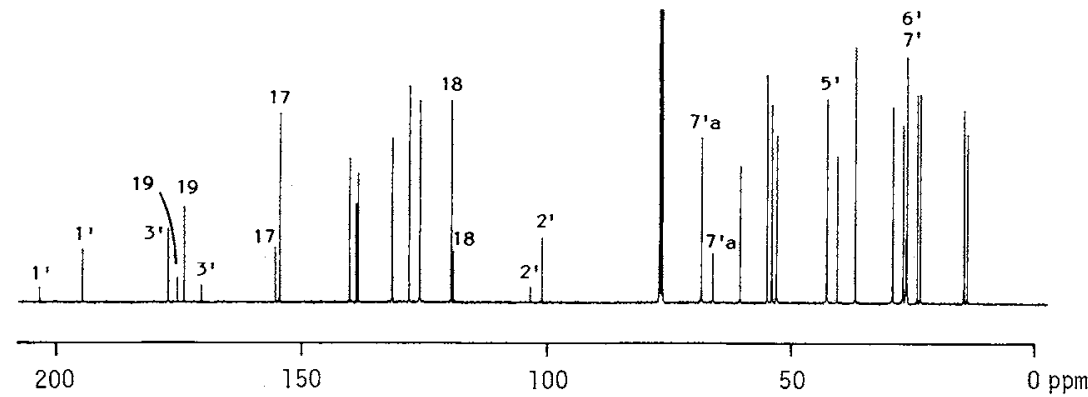


Fig. 4. Long range ${ }^{1} \mathrm{H}^{13} \mathrm{C}$ correlation of pyrrolizidine part of PF1018.

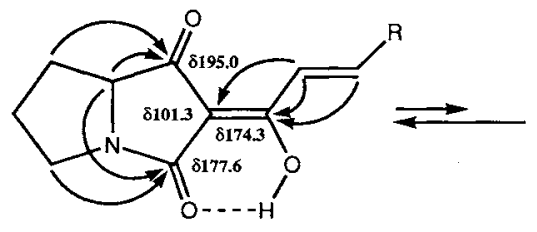

Major form



Minor form

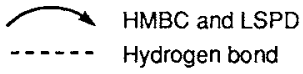

spectroscopy (HMBC) and long range selective proton decoupling (LSPD) experiments were carried out. The ${ }^{1} \mathrm{H}-{ }^{1} \mathrm{H}$ COSY and ${ }^{1} \mathrm{H}-{ }^{13} \mathrm{C}$ COSY spectra revealed the existence of an $E$ olefin $(\mathrm{C}-17, \mathrm{C}-18)$ as indicated by $J_{17-\mathrm{H}, 18-\mathrm{H}}(15.6 \mathrm{~Hz})$ for minor form of 1 and of a partial sequence of $\mathrm{N}-\mathrm{CH}-\mathrm{CH}_{2}-\mathrm{CH}_{2}-$ $\mathrm{CH}_{2}-\mathrm{N}$ which was deduced to be an $N$, 2-disubstituted pyrrolidine moiety $\left(\mathrm{C}-5^{\prime} \sim \mathrm{C}-7^{\prime}\right.$ a) because there was only one nitrogen atom in the molecule. Moreover, long range couplings between $\mathrm{C}-1^{\prime}(\delta 195.0 / \delta$ $203.7) \sim$ one of $7^{\prime}-\mathrm{H}_{2}(\delta 1.55), \mathrm{C}-1^{\prime} \sim 7^{\prime} \mathrm{a}-\mathrm{H}(\delta 3.96 / \delta 4.06), \mathrm{C}-3^{\prime}(\delta 177.6 / \delta 170.8) \sim 5-\mathrm{H}_{2}(\delta 3.27, \delta 3.75 / \delta$ $3.22, \delta 3.79$ ) and C-3' $\sim 7^{\prime}$ a-H were observed in the HMBC and LSPD spectra of 1. Simultaneously, the spectra gave a long-range correlation pattern among 17-H, 18-H, C-19 and C-2' as shown in Fig. 4. These results showed the presence of two carbonyl groups $\left(\mathrm{C}-1^{\prime}, \mathrm{C}-3^{\prime}\right)$ attached to $N$ and 2 positions of the pyrrolidine moiety and a conjugated diene bearing an enolic hydroxyl group $(\delta 174.3, \delta 175.7$ for $\mathrm{C}-19$

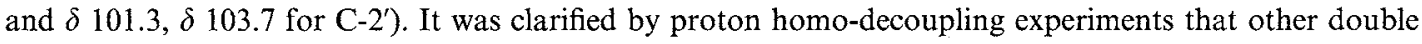
bonds existing in 1 were independent in the molecule, so that the diene and the two carbonyl groups should be connected at C-2' to form a chromophore which was 2- $\alpha, \beta$-unsaturated acylpyrrolizidine-1,3dione skeleton shown in Fig. 4. The characteristic UV spectra $\left(\lambda_{\max }^{\mathrm{MeOH}} 320 \mathrm{~nm}, \lambda_{\max }^{\mathrm{MeOH}-\mathrm{HCl}} 332 \mathrm{~nm}, \lambda_{\max }^{\mathrm{MeOH}-\mathrm{NaOH}}\right.$ $316 \mathrm{~nm}$ ) of 1 closely resembled those of capsimycin $\left(\lambda_{\max }^{\mathrm{MeOH}-\mathrm{HCl}} 325 \mathrm{~nm}, \lambda_{\max }^{\mathrm{MeOH}-\mathrm{NaOH}} 320 \mathrm{~nm}\right)^{2,3)}$ and that of ikarugamycin $\left(\lambda_{\max }^{\mathrm{MeOH}} 325 \mathrm{~nm}\right)^{4,5)}$ possessing a 3- $\alpha, \beta$-unsaturated acylpyrrolidine-2,4-dione chromophore. Structural investigations of $\beta, \beta^{\prime}$-triketones such as 3-acylpyrrolidine-2,4-diones have been reported in detail. $^{6,7)}$ In the reports, it was found that the predominant tautomers in tenuazonic acid were the two exo-enol forms like as those in 1 in less- or non-polar solvents such as $\mathrm{CDCl}_{3}$. It is known that a hydrogen-bonded carbonyl carbon resonates at lower field than a corresponding free carbonyl carbon, therefore, the major tautomer of 1 is considered to exist in $\mathrm{CDCl}_{3}$ as the form having hydrogen-bond between an amide oxygen and an enolic hydroxyl proton (12.35 ppm for 19-OH). The ratio (major form/minor form) of the tautomers in 1 was 3.2 constant from a range of $23^{\circ} \mathrm{C}$ to $60^{\circ} \mathrm{C}$ in $\mathrm{CDCl}_{3}$.

The remaining structural part of 1 is a hydrocarbon $\left(\mathrm{C}_{18} \mathrm{H}_{25}\right)$ containing three double bonds, hence, the fragment is tricyclic. In the ${ }^{1} \mathrm{H}$ NMR spectrum, 1 had six clearly resolved methyl signals. All correlation peaks among the methyl protons and the other carbons within two or three bonds were observed as shown in Fig. 5. Analysis of the HMBC spectrum of 1 in the methyl region and the presence of a single bond between $\mathrm{C}-3 \mathrm{a}$ and $\mathrm{C}-7 \mathrm{a}\left(J_{3 \mathrm{a}-\mathrm{H}, 7 \mathrm{a}-\mathbf{H}}=9.7 \mathrm{~Hz}\right)$ simply led to a bicyclic structure except for a bond between C-3a and C-4 (Fig. 5). Though the $3 \mathrm{a}-\mathrm{H} \sim 4-\mathrm{H}$ coupling constant was nearly $0 \mathrm{~Hz}$, the correlation peaks between $\mathrm{C}-3 \mathrm{a}, \mathrm{C}-7 \mathrm{a}$ and $4-\mathrm{H}$, and between $\mathrm{C}-4$ and $7 \mathrm{a}-\mathrm{H}$ were clearly observed in the HMBC and long range ${ }^{1} \mathrm{H}^{13} \mathrm{C}$ COSY spectra of 1 . Accordingly, $\mathrm{C}-3 \mathrm{a}$ should be attached to $\mathrm{C}-4$ and the unique 
Fig. 5. HMBC spectrum of tricyclic moiety of PF1018.
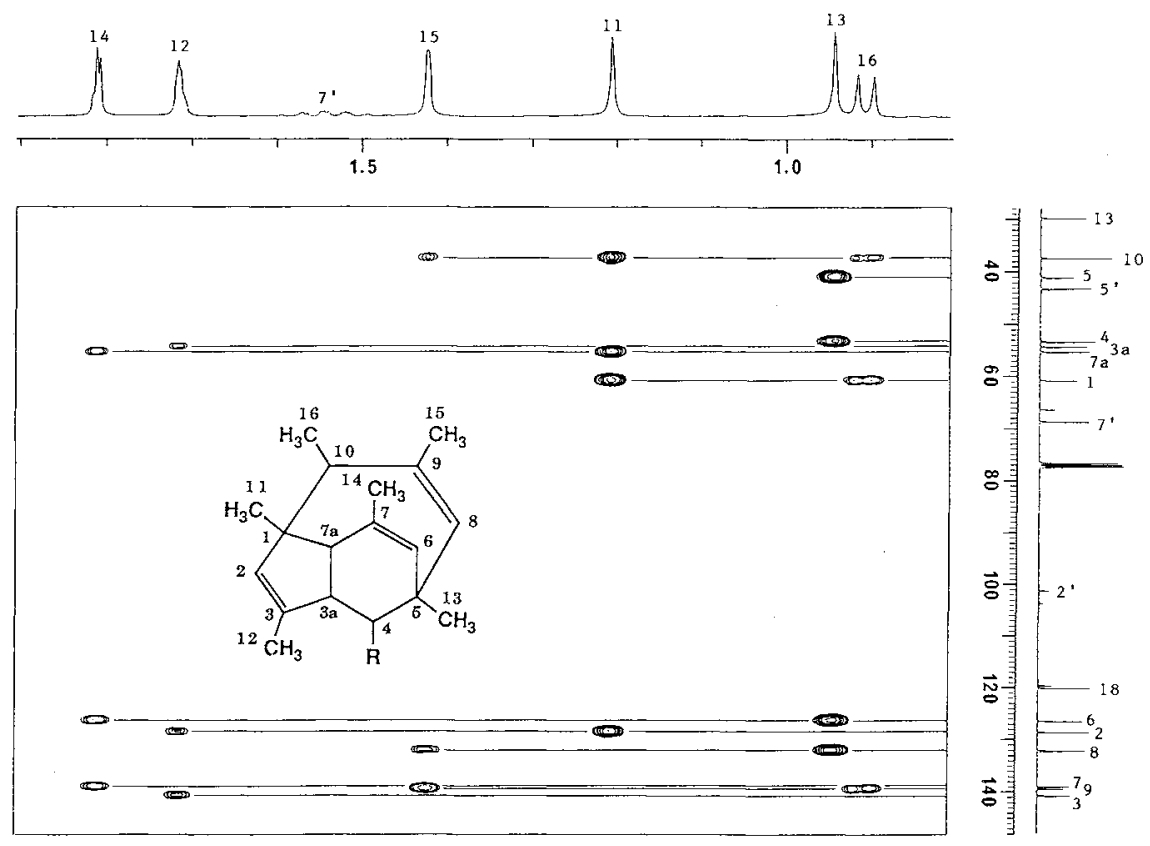

tricyclic hydrocarbon skeleton could be built. Moreover, $\mathrm{C}-4$ of the tricyclic moiety could be connected with $\mathrm{C}-17$ of another part in view of $J_{4-\mathrm{H}, 17-\mathrm{H}}(10.1 \mathrm{~Hz}$ for minor form). From the above-mentioned results, the plane structure of 1 was established to be 2-(1-hydroxy-3-(3a,4,5,7a-tetrahydro-1,3,5,7-tetramethyl5,1-(2,3-dimethylpropeno)-1 $H$-inden-4-yl)-2-propenylidene)pyrrolizidine-1,3-dione.

The relative stereochemistry for six asymmetric centers in the tricyclic moiety was determined mainly by difference NOE experiments shown in Fig. 6. Irradiation of the signal for $11-\mathrm{H}_{3}$ brought about the strong NOE to $7 \mathrm{a}-\mathrm{H}$ signal, therefore, $\mathrm{C}-11$ and $7 \mathrm{a}-\mathrm{H}$ are on the same side of a cyclopentene ring. If a tetrahydro- $1 H$-indene moiety were a trans fused-ring, the propenylidene chain $(\mathrm{C}-8 \sim \mathrm{C}-10)$ could not be connected to $\mathrm{C}-1$ and $\mathrm{C}-5$ from the point of view of bond distance. Consequently, one pair of bridgehead protons $(3 \mathrm{a}-\mathrm{H}$ and $7 \mathrm{a}-\mathrm{H})$ should be $c i s$, and also $\mathrm{C}-5$ configuration is forced by the constraints of ring closure. A large coupling constant $\left(J_{3 \mathrm{a}-\mathrm{H}, 7 \mathrm{a}-\mathrm{H}}=9.7 \mathrm{~Hz}\right)$ indicated the presence of an acute dihedral angle between $3 \mathrm{a}-\mathrm{H}$ and $7 \mathrm{a}-\mathrm{H}$. While $3 \mathrm{a}-\mathrm{H}$ and $4-\mathrm{H}$ orient on the opposite side of a cyclohexene ring in view of the NOE from $12-\mathrm{H}_{3}$ to $4-\mathrm{H}$ and of the $3 \mathrm{a}-\mathrm{H} \sim 4-\mathrm{H}$ coupling constant $(c a .0 \mathrm{~Hz})$. Moreover, the stereochemistry at $\mathrm{C}-10$ was confirmed by the NOE's from $16-\mathrm{H}_{3}$ to $2-\mathrm{H}$ and $15-\mathrm{H}_{3}$, from $10-\mathrm{H}$ to $6-\mathrm{H}$ and $14-\mathrm{H}_{3}$, and from $14-\mathrm{H}_{3}$ to $10-\mathrm{H}$. From these results, the relative configuration of the tricyclic moiety was determined as shown in Fig. 7. The relative stereochemistry at C-7'a of the pyrrolizidine part in 1 was verified as shown in Fig. 7 by a single crystal X-ray diffraction analysis. A PULTO drawing of 1 is shown in Fig. 8. This tautomer in the crystalline state is as the same form which is the main tautomeric species of 1 in $\mathrm{CDCl}_{3}$.

Finally, the absolute configuration of 1 was proved by chemical degradation study. Treatment of 1 with sodium hypochlorite gave $N$-dichloroacetyl-L-proline $\left([\alpha]_{\mathrm{D}}^{23}-107^{\circ}, \mathrm{H}_{2} \mathrm{O}\right)$, which was hydrolyzed by hydrochloric acid to afford L-proline $\left([\alpha]_{\mathrm{D}}^{22}-86.8^{\circ}, \mathrm{H}_{2} \mathrm{O}\right)$. Therefore, $7^{\prime}$ a position in pyrrolizidine moiety 
Fig. 6. Difference NOE spectra of PF1018.
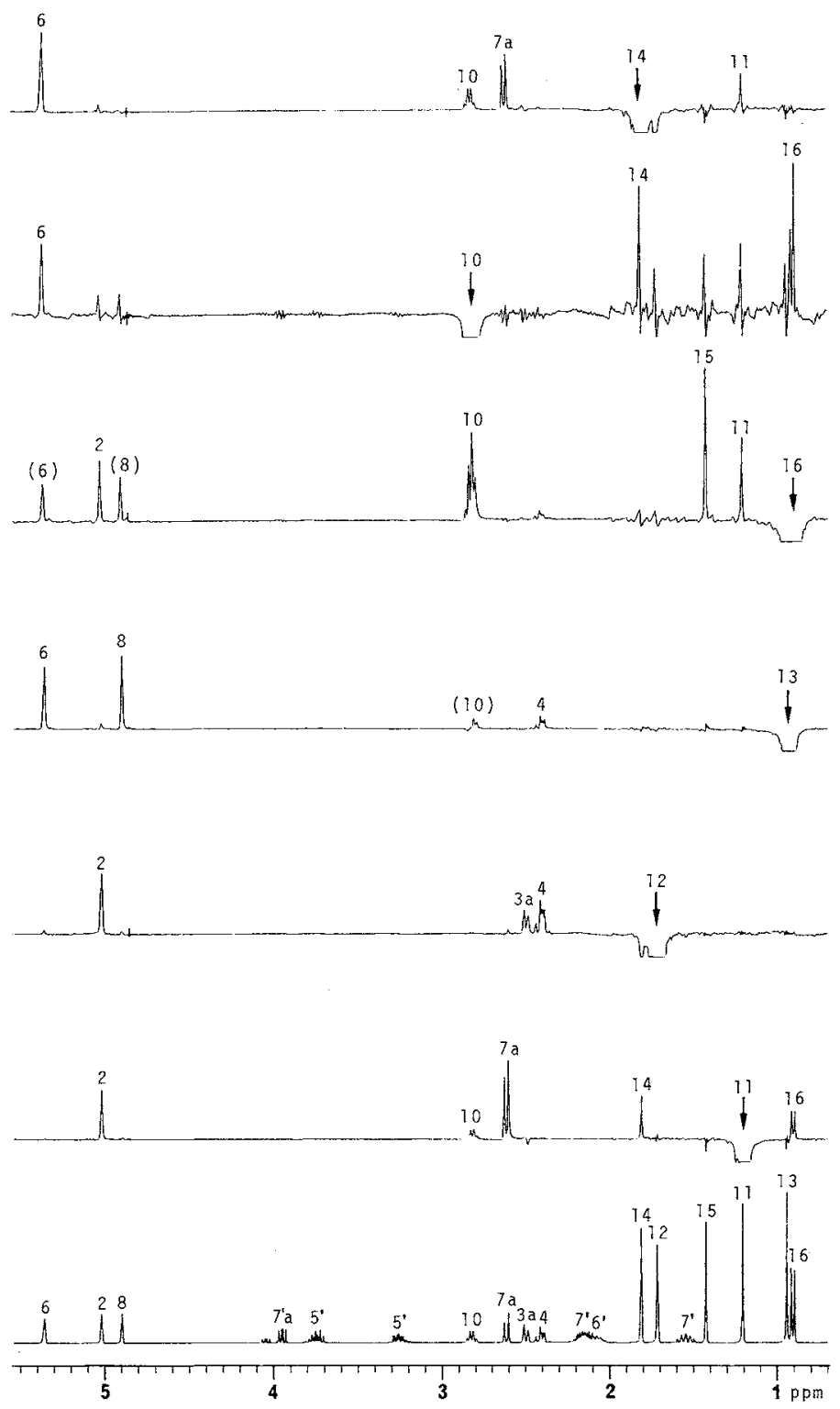

Arrows represent the irradiation signals.

is $S$ configuration. Consequently, the absolute configuration of 1 was determined to be $1 S, 3 R, 4 R, 5 R$, $7 \mathrm{a} R, 10 \mathrm{~S}, 7^{\prime} \mathrm{a} S$ as shown in Fig. 7.

\section{Biological Activities}

As shown in Table 4, PF1018 exhibited insecticidal activity against the important pest species, Plutella xylostella (Lepidoptera), Thrips palmi (Thysanoptera) and Tetranychus cinnaberinus (Acarina). Fairly potent activity was observed against Plutella xylostella which is resistant to pyrethroids and organic 
Table 4. Insecticidal activity of PF1018.

\begin{tabular}{lcccc}
\hline \multicolumn{1}{c}{ Species } & Stage & Application & $\begin{array}{c}\text { Concentration } \\
(\mathrm{ppm})\end{array}$ & $\begin{array}{c}\text { Mortality } \\
(\%)\end{array}$ \\
\hline Plutella xylostella $\mathrm{L}$. & $3 \mathrm{~L}$ & Larvae dipping & 12.5 & 90 \\
Thrips palmi Kany & & & 25 & 100 \\
Tetranychus cinnabarinus Boisd. & L & Larvae-leaf dipping & 150 & 76 \\
& & & 300 & 96 \\
\end{tabular}

Test period: 48 hours.

L: Larva.

A: Adult.

Fig. 7. The absolute structure of PF1018.

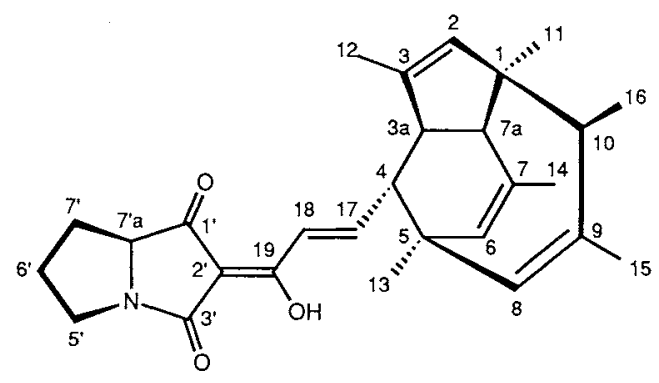

phosphates. At a drug concentration of 25 ppm for 2 days, all larvae were dead with very slight feeding traces on the diet cabbage leaf. A 17,18-dihydro derivative prepared by hydrogenolysis of PF1018 was less than 5\% as active as PF1018. This suggest that the diene and triketone conjugated system play an important role for insecticidal activity. When tested in mice, the acute $L_{50}$. values of PF 1018 were $37 \mathrm{mg} / \mathrm{kg}$ by the oral administration and $1.25 \sim 2.5$ $\mathrm{mg} / \mathrm{kg}$ by the intraperitoneal administration, respectively. Detailed insecticidal activity and the mode of action of PF1018 will be reported elsewhere.

\section{Experimental}

\section{General Procedure}

UV and IR spectra were recorded on a Shimadzu UV-260 and a Shimadzu FTIR-8100 spectrophotometers, respectively. ${ }^{1} \mathrm{H}$ and ${ }^{13} \mathrm{C}$ NMR spectra were recorded on a JEOL JNM-GSX400 spectrometer. The internal standards were used TMS in $\mathrm{CDCl}_{3}$ and sodium 3-trimethylsilylpropane sulfonate and dioxane in $\mathrm{D}_{2} \mathrm{O}$. Mass spectra were recorded with Hitachi M-80B mass spectrometer. Optical rotations were measured on a JASCO DIP-370 digital polarimeter using 10-cm cell. MP was determined with a Yanaco MP-S3 micro melting point apparatus and was uncorrected. TLC was done on a Silica gel $60 \mathrm{~F}_{254}$ plate (Merck, Art. No. 5715).

\section{HPLC Analysis}

Three ml of ethyl acetate was added to an equal volume of sample broth and the mixture was stirred effectively for 10 minutes. One $\mathrm{ml}$ portion of the organic layer was evaporated to dryness. The residue was dissolved with $0.5 \mathrm{ml}$ of $\mathrm{MeOH}$. Ten $\mu$ l of this solution was applied to a Shimadzu HPLC system 
composed of Shimadzu LC-6A pump, Shimadzu SPD-6A UV detector and Chromatopac R-C6A data module. The reversed phase ODS-H $\mathrm{C}_{18}$ column (4.0 i.d. $\times 150 \mathrm{~mm}$, Shimadzu Techno-Research, Inc.) was used and operated at $25^{\circ} \mathrm{C}$ and a flow rate of $1.0 \mathrm{ml} / \mathrm{minute}$, using a $5: 1$ mixture of $\mathrm{MeOH}$ and $0.02 \mathrm{M}$ $\mathrm{KH}_{2} \mathrm{PO}_{4}$ as a mobile phase. $\mathrm{PF} 1018$ was detected at $320 \mathrm{~nm}$ and eluted as a sharp peak at 4.6 minutes.

\section{Single-crystal X-Ray Diffraction Analysis}

The transparent prismatic crystals were obtained by diffusing hexane to $\mathrm{CHCl}_{3}$ solution of $\mathrm{PF} 1018$ through gas phase. The crystal having approximate dimensions of $0.2 \times 0.2 \times 0.2 \mathrm{~mm}$ was mounted on a glass fiber. All X-ray measurements were made on a Rigaku AFC5R diffractometer with graphite monochromated $\mathrm{CuK} \alpha$ radiation and a $3 \mathrm{Kw}$ rotating anode generator. Cell constants and an orientation matrix for data collection were obtained from a least-squares refinement using the setting angles of 25 reflections in the $2 \theta$ range $22 \sim 47^{\circ}$.

The crystal system was orthorhombic, space group $P 2{ }_{1} 2_{1} 2_{1}$, with unit cell dimensions $a=15.993(2) \AA$, $b=19.184(2) \AA, c=8.0523(6) \AA, V=2470 \AA^{3}, Z=4$. The data were collected using the $\omega-2 \theta$ scan mode to a maximum $2 \theta$ value of $120^{\circ}$. Scans of $(1.25+0.3 \tan \theta)^{\circ}$ were made at a speed of $16^{\circ} /$ minute in omega. The weak reflections $(I<10 \sigma)$ were rescanned twice and the ratio of peak counting time to background counting time was $2: 1$. A total of 2132 reflections was collected. Azimuthal scans of several reflections indicated no need for an absorption correction. The data were corrected for Lorentz and polarization effects.

The structure was solved by direct methods which were given in the MITHRIL ${ }^{8)}$ software package. The non-hydrogen atoms were refined anisotropically including the hydrogen atoms in calculated positions. The final cycle of full matrix least square for the 1069 reflections $(I>3 \sigma)$ and 289 variable parameters gave an $\mathrm{R}$ value of 0.54 . The maximum and minimum peaks in the final difference Fourier map corresponded to 0.26 and $-0.21 \mathrm{e} / \AA^{3}$, respectively.

\section{Chemical Degradation}

Three $\mathrm{ml}$ of $\mathrm{NaClO}$ solution ( $c a .10 \% \mathrm{Cl}_{2}$ ) was added to a solution of $\mathrm{PF} 1018(56.0 \mathrm{mg}$ ) in $\mathrm{MeOH}$ $(50 \mathrm{ml})$ and the mixture was stirred for 20 minutes at room temperature. The reaction mixture was concentrated to dryness. The residue was dissolved in water $(10 \mathrm{ml})$, washed twice with $\mathrm{CHCl}_{3}(10 \mathrm{ml})$ and the aqueous layer was evaporated to dryness. The residual solid was extracted with dry $\mathrm{MeOH}$. Further purification was achieved by Sephadex LH-20 $(100 \mathrm{ml})$ column chromatography developed with $\mathrm{MeOH}$ to give $N$-dichloroacetyl-L-proline $(20.3 \mathrm{mg}, 69.6 \%$, trans form: cis form, $6: 1): \mathrm{C}_{7} \mathrm{H}_{9} \mathrm{Cl}_{2} \mathrm{NO}_{3}$, EI-MS; $225\left(\mathrm{M}^{+}\right), 227(\mathrm{M}+2)^{+}, 229(\mathrm{M}+4)^{+},[\alpha]_{\mathrm{D}}^{23}-107^{\circ}\left(c 1.0, \mathrm{H}_{2} \mathrm{O}\right),{ }^{1} \mathrm{H}$ NMR $\left(\mathrm{D}_{2} \mathrm{O}\right)$ trans form: $\delta 4.51(\mathrm{dd}$, $J=8.7,4.4 \mathrm{~Hz}, 2-\mathrm{H}), 2.09$ and $2.36\left(\mathrm{~m}, 3-\mathrm{H}_{2}\right), 2.09\left(\mathrm{~m}, 4-\mathrm{H}_{2}\right), 3.79\left(\mathrm{~m}, 5-\mathrm{H}_{2}\right), 6.73\left(\mathrm{~s}, \mathrm{COC} H \mathrm{Cl}_{2}\right)$; cis form: $\delta 4.82(\mathrm{dd}, J=7.7,3.8 \mathrm{~Hz}, 2-\mathrm{H}), 2.09$ and $2.36\left(\mathrm{~m}, 3-\mathrm{H}_{2}\right), 1.89$ and $2.03\left(\mathrm{~m}, 4-\mathrm{H}_{2}\right), 3.56$ (ddd, $J=12.1,9.5$, $7.2 \mathrm{~Hz}, 5-\mathrm{H}), 3.67(\mathrm{ddd}, J=12.1,8.7,3.1 \mathrm{~Hz}, 5-\mathrm{H}), 6.60\left(\mathrm{~s}, \mathrm{COCHCl}{ }_{2}\right) ;{ }^{13} \mathrm{C} \mathrm{NMR}\left(\mathrm{D}_{2} \mathrm{O}\right)$ trans form: $\delta 61.2$ $(\mathrm{d}, \mathrm{C}-2), 29.6(\mathrm{t}, \mathrm{C}-3), 25.2(\mathrm{t}, \mathrm{C}-4), 48.7(\mathrm{t}, \mathrm{C}-5), 175.9(\mathrm{~s}, \mathrm{COOH}), 165.5\left(\mathrm{~s}, \mathrm{COCHCl}_{2}\right), 65.9\left(\mathrm{~d}, \mathrm{COCHCl}_{2}\right) ;$ cis form: $\delta 61.3(\mathrm{~d}, \mathrm{C}-2), 31.6(\mathrm{t}, \mathrm{C}-3), 22.6(\mathrm{t}, \mathrm{C}-4), 48.9(\mathrm{t}, \mathrm{C}-5), 176.0(\mathrm{~s}, \mathrm{COOH}), 166.2\left(\mathrm{~s}, \mathrm{COCHCl}_{2}\right)$, $65.6(\mathrm{~d}, \mathrm{COCHCl})$.

$N$-Dichloroacetyl-L-proline $(17.5 \mathrm{mg})$ in $6 \mathrm{~N} \mathrm{HCl}(2 \mathrm{ml})$ was heated at $110^{\circ} \mathrm{C}$ in a sealed tube for 15 hours and the reaction mixture was concentrated to dryness. The residue was dissolved in $\mathrm{H}_{2} \mathrm{O}$ and adsorbed on a column of Diaion PK-208 $\left(\mathrm{H}^{+}, 2 \mathrm{ml}\right)$. The column was washed with $\mathrm{H}_{2} \mathrm{O}$ and eluted with $0.5 \mathrm{~N} \mathrm{NH}_{4} \mathrm{OH}$. The Ninhydrin-positive fraction was concentrated to give L-proline $(6.9 \mathrm{mg}, 77.4 \%): \mathrm{C}_{5} \mathrm{H}_{9} \mathrm{NO}_{2}$, EI-MS; $115\left(\mathrm{M}^{+}\right),[\alpha]_{\mathrm{D}}^{22}-86.8^{\circ}\left(c 0.5, \mathrm{H}_{2} \mathrm{O}\right),[\alpha]_{\mathrm{D}}^{22}-49.7^{\circ}(c 0.5,0.5 \mathrm{~N} \mathrm{HCl})$.

\section{References}

1) Bertold, M.: New species of Humicola: an approach to genetic and biochemical classification. Can. J. Botany 54: $2755 \sim 2768,1976$

2) Arzawa, S.; H. Akutsu, T. Satomi, T. Nagatsu, R. Taguchi \& A. Seino: Capsimycin, a new antibiotic. I. Production, isolation and properties. J. Antibiotics 32: 193 196, 1979

3) Seto, H.; S. Aizawa, H. Akutsu, K. Furuhata \& H. Yonehara: Studies on new antibiotic capsimycin. II. Structure of capsimycin. Abstracts papers of annual meeting of the Agricultural Chemical Society of Japan, No. 3O-23, p. 369, Tokyo, Apr. 1 4, 1979 (in Japanese) 
4) Jomon, K.; Y. Kuroda, M. AjISAKa \& H. SAKAI: A new antibiotic, ikarugamycin. J. Antibiotics 25: $271 \sim 280,1972$

5) ITO, S. \& Y. Hirata: The structure of ikarugamycin, an acyltetramic acid antibiotic possessing a unique ashydrindacene skeleton. Bull. Chem. Soc. Jpn. 50: 1813 1820, 1977

6) Steyn, P. S. \& P. L. Wessels: Tautomerism in tetramic acids: ${ }^{13} \mathrm{C}$ NMR determination of the structures and ratios of the tautomers in 3-acetyl-5-isopropylpyrrolidine-2,4-dione. Tetrahedron Lett. 1978: 4707 4710, 1978

7) Nolte, M. J.; P. S. Steyn \& P. L. Wessels: Structural investigation of 3-acylpyrrolidine-2,4-diones by nuclear magnetic resonance spectroscopy and X-ray crystallography. J. Chem. Soc. Perkin Trans. I 1980: 1057 1065, 1980

8) Gilmore, C. J.: MITHRIL-an integrated direct method computer program. J. Appl. Cryst. 17: 42 46, 1984 